\title{
The impact of traditional and social media marketing on customers' brand trust and purchase intentions in the Turkish airline market
}

\author{
Mustafa Tümera, Iman Aghaeib*, Emrah Öneyc, Yahya Nasser Eddined \\ a,b,c,d Faculty of Business and Economics, Eastern Mediterranean University, Famagusta, North Cyprus, via Mersin 10, \\ Turkey.E-mail addresses: ${ }^{a}$ mustafa.tumer@emu.edu.tr, ${ }^{b}$ iman.aghaei@emu.edu.tr, ${ }^{c}$ emrah.oney@emu.edu.tr, \\ dyahya.nasser.edu@gmail.com. \\ ${ }^{*}$ Corresponding author.
}

Received: 26 June 2019, revised: 11 December 2019, accepted: 12 December 2019, published: 14 December 2019.

\begin{abstract}
The purpose of this study is to investigate the effect of customers' attitudes towards traditional and social media marketing on brand trust and purchase intention. Reviewing the extant literature unveiled that the subject of traditional versus social media marketing in the airline market is not sufficiently studied. Thus, we studied the mentioned subject in Turkey because the aviation sector has shown noteworthy improvements due to a significant increasing volume of e-commerce, not only on the passenger side but also on the cargo side as well. On the other hand, thanks to the passenger demand growth since starting the recent century, the Turkish airline industry leads a giant contribution to the enlargement of the global economy due to the increasing number of connections and falling air transport costs. Data was gathered in Istanbul airports from 341 passengers of the airlines of Turkey to compare the impact of traditional and social media marketing on brand trust and purchase intention of customers and analyzed by using structural equation modeling. The findings reveal that in recent years digital marketing and online advertising campaigns has been more effective than traditional marketing for augmenting brand trust and purchase intention of the passengers.
\end{abstract}

Keywords: traditional marketing; social media marketing; brand trust; purchase intention; structural equation modeling (SEM); Turkish airline market.

JEL codes: M31, N70.

\section{INTRODUCTION}

During the 1980s, the development of the travel and tourism industry was coincident with the amplifying trend of the air transportation industry in Turkey. Turkey due to its geographical locality performs alike a crossway surrounded by Europe, the Middle East, and Asia (Torlak et al., 2011). Therefore, this geographical endowment gave the chance to the Turkish Airlines company ${ }^{1}$ and the other private airlines in Turkey to fortify their fleets (Sevkli et al., 2012).

In continue, the air transportation policy of Turkey was rehabilitated at the end of 2003 , so that limitations on private airlines were improved entirely and for additional incentivizing the flight' tax was diminished. Likewise, this opportunity was the preamble of huge competition in the Turkish airline market where they were growing promptly (Ülkü, 2015; Orhan \& Gerede, 2013).

Turkey has escalated to a significant position in the international civil aviation field with the records broken in air traffic and the number of passengers (Aksoy \& Dursun, 2018). According to Republic of Turkey General Directorate of Civil Aviation (SGHM) annual reports 2018, Turkish airline industry's annual turnover is

1 The State Airlines Administration was founded on 20 May 1933 in connection with the Ministry of Defence (https://investor.turkishairlines.com/en/turkishairlines/history).

http://dx.doi.org/10.30585/jrems.v1i4.344

(c) 2019 the Authors. Production and hosting by Avicenna FZ LLC. on behalf of Dubai Business School, University of Dubai, UAE. This is an open-access article under the CC BY 4.0 license (https://creativecommons.org/licenses/by/4.0/). 
approximately 30 billion U.S dollars and it accounts for the $3.86 \%$ of Turkey's GDP (app. 784 billion U.S dollars), and the total quantity of personnel is more than 200,000 . The aviation sector chased its evolution trend, enlarging the number of aircraft and passengers. The number of international destinations increased to 261 in 112 countries, and the number of domestic destinations to 55. The figure of around 180 million passengers, affirms almost 200 percent growth compared with 2006. Right now, there is a drastic increase in the number of wide-body aircraft in Turkish airline routes from 259 to more than 500 while it demonstrates the seats capacity growth from 42,335 to 90,259 (Atalık \& Arslan, 2009).

Although its momentous place in the Turkish economy, not enough devotion has been given to civil aviation research. In this research, a neglected sector will be examined in-depth and the most efficient marketing method (tradition vs. social media marketing) for airline customers will be questioned through the examination of consumers' attitudes. The result of this research can be employed by the sector for better marketing spending and efficient management.

Todur (2016) defined traditional marketing as buying attention through tangible items such as business cards, posters and print arts in magazines and newspapers. It also includes TV and radio commercials. Mostly, traditional marketing is employed to reach a national or local audience. On the other hand, Wsi $(2013$, p. 7$)$ defined digital marketing as "the practice of promoting products and services innovatively, using primarily database-driven distribution channels to reach consumers and customers in a timely, relevant personal and cost-effective manner is known in the theory and practice as digital marketing". Digital marketing can also be used to target national or local audiences as well as international ones. From the airline industry perspective, companies are generally employing both methods to reach national and international customers. The following Table 1 shows the main advantages and disadvantages of both methods:

Table 1. Comparison of main advantages and disadvantages of traditional and digital marketing

\begin{tabular}{c|c}
\hline \multicolumn{1}{c|}{ Traditional marketing } & \multicolumn{1}{c}{ Digital marketing } \\
\hline Advantage & Advantage \\
The level of trust & Cost efficiency \\
Durability & Interactivity \\
Faster Results & Active User Approach \\
& Easy Measurable \\
& Personalized \\
Disadvantage & \\
High Cost & Disadvantage \\
Timing & The copyright problems \\
Difficulties in measuring success & The lack of user trust \\
Lack of interactivity & Not embraced by everyone \\
& It can take some time to achieve observable \\
\hline
\end{tabular}

Over the past few years, many airline service companies have realized the need to engage with a social media platform to communicate with a large number of their existing and potential customers (Hsu, 2012). The main advantages of marketing on social media are cost-related (Weinberg, 2009). Also, new internet-based technologies for dispatching information about brands increased the speed flow of information among consumers (Zarrella, 2010). Furthermore, the study of Aghaei and Sokhanvar (2019) reveals that there is a positive association between e-commerce adoption and companies' innovativeness.

Marketing specialists have started to utilize social networking platforms for their advertising aim to make the products more appealing for consumers and grab their attention in a more customized and tailored-manner (Waters et al., 2011). Firms are always keen to create advertisements that have a chance of going viral to create a wave among customers that find them trustworthy, and to influence other neutral customers consequently (Hoy and Milne, 2010). While consumers hold the power of increasing the views of a message, image or video created by the advertisers, they become socially engaged in expanding the targeted segments to reach their contacts through reposting or sharing the message on their profiles (Rodgers et al., 2013). The majority of consumers who join a company's group or follow its social media, start receiving information that may eventually influence their perception and purchase intention in the future (Zhao et al., 2008).

For instance, as of November 2015, Qatar Airways ranked first on top of the list with the highest number of likes on its Facebook page with 10.3 million "likes", followed by KLM 9.8 million, Turkish Airlines with 7.4 million, and Air France with 5.3 million. At first glance, these airlines may seem to be performing very well, taking into consideration the number of followers on social media. However, the number of followers on a page is not a reliable measurement of performance (Preece et al., 2004). 
It is valuable to attempt to identify the reasons behind marketers' high expectations of using social media as a marketing tool, and what advantages might hold over classical marketing strategies and channels (Waters et al., 2011; Hill \& Moran, 2011).

Nevertheless, most of the brands still do not believe social networks as an engine for absorbing customer loyalty and creating brand awareness, however, it becomes a reality that companies' investment in social media has been escalated during the recent years. This directs a worthwhile circumstance for marketing managers to attain customers' purchase intention: Social media marketing (Gamboa \& Gonçalves, 2014).

Researching in this field, some researchers have concentrated on understanding the predictors of retention (Lin \& Lu, 2010; Zeithaml, 1988), while others consider interactions and encounters with customers, and overall customer experience more relevant to realizing the purchase intention. Thus, this study aims to fill some of the gaps that abound in the relation of marketing literature regarding customers' purchase intentions in the context of the airline industry.

The main contribution of this study is that customers' attitudes towards both social media and traditional marketing have been measured simultaneously which provided the chance to compare the effect of two marketing methods on trust formation. By comparing the effect of these two methods, the study created the chance for companies which method should be preferred to build brand trust.

The article proceeds as follows: Section 2 reviews the extant literature and hypotheses designation. Section 3 demonstrates the constructs, data collection, and analysis. Section 4 evaluates the findings. Section 5 presents the managerial and theoretical implications of the findings. Lastly, Section 6 describes the limitations and suggestions for future research.

\section{LITERATURE REVIEW AND HYPOTHESIS DEVELOPMENT}

In order to form the conceptual model of study, we review the literature on traditional and social media marketing, brand trust, and purchase intention. Based on this review, we demonstrate the relationships between the constructs using theoretical evidence. Moreover, a review of the literature displays the aforementioned constructs have been considered in different combinations, although the constructs have not been investigated in the particular composition portrayed here and in the context of the airline market. Hence, the foundation for the present research study is prepared by the following hypotheses:

\subsection{Traditional marketing and brand trust}

Traditional methods of marketing typically involve advertising through newspapers, magazines, radios, televisions and direct mail, which can be described in different ways, but to explain its low level of interactivity, we must understand its nature. Traditional advertising denies customers' ability to control the amount, type and order of information that they receive. This is called a linear model of communication (Lavinsky, 2013). Marketing researchers have also argued that traditional advertising still has many effects on consumers' perception and reaction to an advertisement's content. Factors they are affected by could be brand loyalty, trust, involvement, mood, cognition, recall, and attitudes (De Pelsmacker et al., 2002; Moorman et al., 2002). A frequently presented brand placement through traditional marketing campaigns can have a positive effect on brand evaluations and trust even if viewers may not recall the brand (Guennemann \& Cho, 2014).

Thus, the following hypothesis is proposed:

H1. Customers' attitudes towards traditional marketing of a company have a positive and significant effect on customers' brand trust.

\subsection{Social media marketing and brand trust}

Introducing the internet into the airline industry allowed airline firms to obtain a competitive advantage, offering lower advertising costs, higher customer satisfaction, marketing success rates and competitiveness (Tsai et al., 2005). Many firms today would count social media as a strategic component of their communicational strategy. Despite, it is still unclear whether social media is an effective marketing strategy and would positively influence customers' brand trust and purchase intentions (Weinberg \& Pehlivan, 2011).

Former studies indicated when customers involve themselves with a brand in social media, a positive assessment of the brand is reflected. Customers may identify themselves with a certain firm through participation on the firm's social media page. This leads to a sort of emotional dependence and dedication to the firm later on. Kim and Ko (2012) and Naylor et al. (2012) have argued that firms also do benefit from using 
social media. These studies also revealed a positive correlation between social media and variables like brand trust, brand evaluation, and purchase intention.

Customer loyalty through social media was studied by Gamboa and Gonçalves (2014) and they considered Zara's Facebook page. By comparing fans and non-fans of the Zara brand, they explored that Facebook intensified the relations that improve brand loyalty via brand trust, customer satisfaction, perceived value, and commitment. According to their results, these relations are stronger for their online fans of the brand than for non-fans.

Several other studies proved the existence of a positive relationship between the social media activity of firms and variables like brand trust, loyalty, evaluation and purchase intention (Kim \& Ko, 2012; Naylor et al., 2012; Schivinski \& Dakabrowski 2013). Such a relationship sounds believable since previous studies have shown that hitting the like button of a firm's page on social media increases the firm's exposure. Hitting the like button usually triggers positive brand-related information, increasing the number of followers who show a higher interest in the firm's services or products. This may lead to a positive effect on the firm's brand trust and evaluation (Beukeboom et al., 2015).

Thus, the following hypothesis is proposed:

H2. Customers' attitudes towards social media marketing of a company have a positive and significant effect on customers' brand trust.

\subsection{Brand trust and purchase intention}

Everard and Galletta (2006) conducted a laboratory study to review the influence of brand trust of online shopping on consumers' purchase intentions. They found a positive association between online created brand trust and purchase intentions. Aghekyan-Simonian et al. (2012) studied online purchase intention and demonstrated that brand trust positively influenced purchase intention by reducing the level of perceived risk. Mansour et al. (2014) also performed a similar study with a more complex combinatory approach to reveal the causes and outcomes of online brand trust and concluded that online brand trust does affect purchase intention.

Although there is a difference between brand trust and loyalty, brand trust is still viewed as a variable that has a great influence on purchase intention (Sung \& Kim, 2010). Brand trust directly influences purchase intention and is of extreme relevance when a customer decides to change a brand because of high-perceived risk and obscurity levels (Ibáñez et al., 2006). Ling et al. (2011) were also supporters of the claim of a positive relationship between brand trust and purchase intention.

Mohamed et al. (2014) published a paper to provide insights about individuals' online purchase intentions. The research model was developed in consonance with the Expectation Confirmation Theory and Technology Acceptance Model as theoretical grounds. To achieve the aim of the study, a cross-sectional survey was conducted and using a convenience sampling technique, data were obtained from an online marketplace website that connects buyers and sellers in Malaysia. The findings disclose customers' satisfaction contributes to individual online purchase intention.

Hsu, Chang, and Chuang (2015) researched to understand the determinants of online purchase intention. In this study, they offered a theoretical model by integrating the literature of expectation-confirmation model and online shopping. The research sample includes 246 responders to test the proposed model. The results show that customers' brand trust and satisfaction are the strong predictors of purchase intention.

Zheng, Lee, and Cheung (2017) considered e-loyalty as a key to the success of online marketing. The purpose of this study was to advance the theoretical understanding of e-loyalty in the context of online platforms. The research model was tested using a sample of 537 customers of an online platform in a longitudinal setting. All designed hypotheses in the research were supported. Specifically, the authors found the significant impact of brand trust on loyalty intention.

Saleem, Zahra, and Yaseen (2017) have also conducted a study to examine the antecedents of purchase intention in the Pakistani airline industry. They stated that traditional studies on purchase intention have more concentration on service quality and satisfaction, however recent researches have proposed that brand trust plays a pivotal role in driving purchase intention for Pakistan's airline industry. They employed structural equation modeling to test the hypotheses of relationships among antecedents of purchase intention. In doing so, 383 frequent customers of Pakistani airlines were selected. Their findings showed that service quality and trust are directly associated with purchase intention as well as through the mediator of customer satisfaction.

Thus, the following hypothesis is proposed:

H3. Customers' brand trust has a positive and significant effect on customers' purchase intention. 
As explained so far, three hypotheses were proposed to consider the aim of the study. Based on the developed hypotheses, the research model is illustrated in Figure 1 as below:

Figure 1. Research model

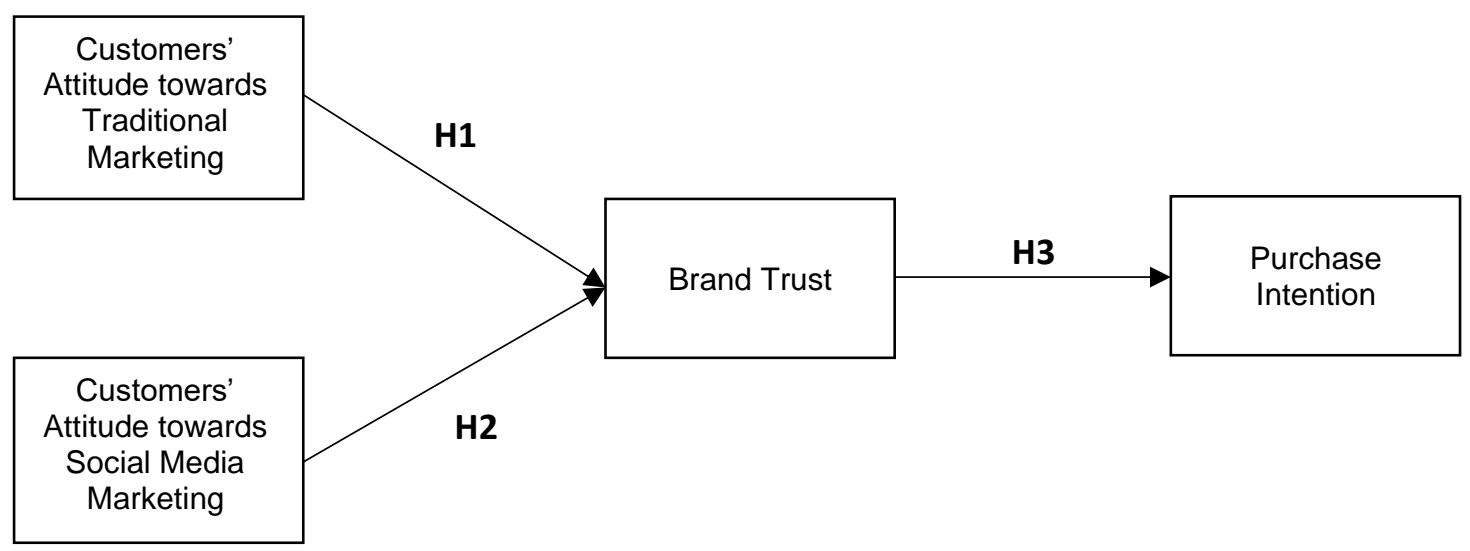

\section{RESEARCH METHODOLOGY}

\subsection{Concepts and definitions}

\subsubsection{Traditional Marketing}

Traditional marketing tools are television, newspapers, radio, and magazines which are considered one-way and static broadcasting technologies (Zarrella, 2010). Traditional marketing is a highly competitive environment, which creates a fragile medium for retailers who still operate the old-fashioned way (Wongleedee, 2015). Many factors may lead to the unprofitability of these old-fashioned operators in the markets, such as changes in tastes, values, changing lifestyles, purchasing behaviors and competition from international firms. Some traditional marketers might lack the ability to offer attractive prices or advertising campaigns to hold onto their current customers or even prevent them from shifting to competitors (Constantinides, 2006).

Although some scholars may support the decline of traditional media theory, Lavinsky (2013) argued differently and stated that the idea of denying traditional media is not accurate. Questions that have always circulated in the marketing world are: Is marketing the traditional way still profitable? Is it still alive? Is it affordable?

\subsubsection{Social Media Marketing}

Berthon et al. (2012) defined social media as the chain of technological innovations software and hardware that makes it possible to create and integrate inexpensive content by online users. Safko and Brake (2009) defined social media as the set of people's activities and behaviors in online communities to share their information, knowledge, and opinions by conversational media.

In 2013, the Fortune 500 companies list (an annual list assembled and published by Fortune magazine that ranks 500 of the largest US corporations) showed that $70 \%$ of these companies were active on social media (Barnes et al., 2013).

Followers of fan pages on social media of international airlines showed positive feedback scores higher than non-followers (Dijkmans et al., 2015). However, customers who reported positive feedback about a firm's posts on social media also were more likely to have a positive brand attitude and higher purchase intention (Schivinski \& Dabrowski, 2013). Due to the intangibility of services provided by airline companies or hospitality products, online fan pages act as subjective and personal references for customers to learn about the experiences of others (Drury, 2008).

Social media differs from traditional media in two main ways: (a) a shift in the mode of communication from a one-way communication model to a two-way communication type (meaning greater interactivity); (b) a shift in the locus of power from the firm to the consumer. A firm might consider investing the traditional way and embedding some relatively small investments in the online virtual world to diversify its portfolio and reduce loss risks (Lavinsky, 2013). 


\subsubsection{Brand Trust}

Scholars such as Chaudhuri and Holbrook (2001, p. 82) have defined brand trust as "the willingness of the average consumer to rely on the ability of the brand to perform its stated function". In general, academics have agreed that a customer trusts a brand in an uncertain and risky environment when the customer is not certain of the outcome of a decision but that decision is still of relevant importance (Matzler et al., 2006).

$\mathrm{Ha}$ and Perks (2005) defined brand trust as a point when a customer believes that a certain brand or firm will perform as promised or expected upon consuming. Building brand trust requires a well-considered process of creating a relationship between a customer and the brand (Chaudhuri and Holbrook, 2001).

Brand trust is created after a consumer has tried a company's product or service and can now evaluate the company's offerings. For instance, if an airline company promises safety, honesty, and reliable services to its customers, and fulfills its promises, customers will eventually place their trust in that company (Doney and Cannon, 1997).

Sheth and Parvatyar (1995) describe brand trust through customer relationships, which is the alternative to human-company contact. Ballester and Aleman (2005) and Mohammad (2012) have also studied brand trust and stated that brand trust is a valuable mediator in studying customer behavior pre-post purchasing and purchase intention and helps to create and maintain a long-term loyal relationship.

\subsubsection{Purchase Intention}

According to the theory of planned behavior set by Ajzen (1991), purchase intention is defined as a consumer's intention to purchase from a seller residing in the market. This also inspires customers to build a positive "purchase intention-behavior" (McKnight et al., 2002). Willingness to buy or purchase intention can also be defined as: "the likelihood that the buyer intends to purchase the products" (Grewal et al., 1998, p. 48). Zeithaml (1988) added that a customer's decision of whether to buy or not depends heavily on the value of the product or service in the customer's eyes at the first glance, then on the judging and reviewing of other customers' experience.

Fandos and Flavian (2008) defined purchase intention as the promise a consumer makes to him/herself to repurchase a product or service. This is considered crucially important for companies, as the companies aim at increasing their sales and maximizing profits (Tariq et al., 2013).

Kang et al. (2014) specified that there are four consumer behaviors related to purchasing intention: (a) the assured plan of buying the product; (b) thinking undoubtedly of purchasing the product; (c) considering buying the product in the future; (d) buying the specific product. Creating a positive purchase intention behavior is a dynamic process rather than a quiet immobile action. Initially, a consumer collects information about the desired product and evaluates its quality through the benefits received after the own-experience of the product. At this point, if the consumers satisfy with that product or service, they would consider repurchasing from that brand or even at least show enthusiasm towards that particular product. This process is now called "purchase intention". Purchase intentions are affected by several variables, such as product knowledge, product quality, brand trust, etc.

\subsection{Procedure and sample}

To analyze the research model, the respondents were nominated by applying a convenience sampling technique that attempts to obtain a sample of convenient elements in the right place at the right time (Teimouri et al., 2018). Thus, 365 passengers of Turkish airline companies were chosen from the Istanbul airports. The airports are situated at the intersection of Europe and Asia which are the largest aerodrome in Turkey and serves as the central pivot for airlines of Turkey (Aksoy et al., 2003).

For collecting the data, a questionnaire was developed. The forms were arranged in English and Turkish to enhance communication, and the answer rate (Aksoy et al., 2003).

The data collection process went through a pilot study of 40 professionals on the subject before the final crosssectional survey to assess the contents, increase the validity of the questionnaire, and reduce the probable errors. The results of the pre-test provided preliminary evidence of the reliability and validity of the measures. Several words were modified to ensure that the contents could be generalized to the research context and easily understandable by all types of responders. Out of 365 questionnaires were distributed to collect the data, 347 questionnaires were retrieved that six of them were invalid which finally yielded 341 valid responses with a return rate of $93.42 \%$. 


\subsection{Measures}

All measurements of the constructs were carried out using statements adapted from previous studies. At the beginning of the questionnaire, participants were asked to complete a demographic profile, as shown in Table 2:

Table 2. Respondent demographic characteristics $(\mathrm{N}=341)$

\begin{tabular}{lc}
\hline \multicolumn{1}{c}{ Characteristics } & Total \\
\hline Gender & \\
Male & $61.5 \%$ \\
Female & $38.5 \%$ \\
& \\
Age cohorts & \\
-20 & $9.0 \%$ \\
$21-30$ & $25.6 \%$ \\
$31-40$ & $27.8 \%$ \\
$41-50$ & $21.3 \%$ \\
$50+$ & $16.3 \%$ \\
& \\
Marital status & \\
Single & $23.9 \%$ \\
Married & $52.9 \%$ \\
Divorced & $18.3 \%$ \\
Living Together & $4.9 \%$ \\
Employment & \\
Studying & \\
Working & $26.8 \%$ \\
Retired & \\
Unemployed & $40.4 \%$ \\
Income & $18.7 \%$ \\
Lower class & $14.1 \%$ \\
Lower-middle class & \\
Middle class & \\
Upper-middle-class & \\
Upper class & \\
Frequency of annual flights & $7.4 \%$ \\
1-3 times & $11.3 \%$ \\
6-5 times & $48.8 \%$ \\
Frequency of social media visits & $23.2 \%$ \\
Regularly (20 or more times/week) & $9.3 \%$ \\
Often (10-19 times/week) & \\
Rometimes (2-9 times/week) & \\
\hline & \\
\hline
\end{tabular}

The second part consisted of 25 questions in five-point Likert scale type $(1=$ strongly disagree and $5=$ strongly agree) were selected to record their perceptions of variables: traditional marketing, social media marketing, brand trust, and purchase intention.

Initially, the survey covered the traditional marketing perception level (Abzari et al., 2014). Social media marketing perception questions were adopted accordingly from Abzari et al (2014), Dehghani, and Tümer (2015). The next part of the questionnaire posed questions concerned with brand trust among online community members adopted from Kang et al. (2014). Consequently, the questionnaire dealt with the purchase intentions of customers, whether are they still willing to purchase, recommend or stop dealing with the examined airline company (Abzari et al., 2014; Dehghani and Tümer, 2015).

\subsection{Data analysis}

AMOS 23.0 was used to analyze the proposed structural equation model of study and estimate the path coefficient. Before testing the hypothesis by using structural equation modeling, we first conducted a reliability analysis to check the internal consistency of measurement items per variable in different settings and conditions (Vitolins et al., 2000). All items loaded properly on their intended variable, and the overall reliability coefficient 
(Cronbach's alpha) of the questionnaire is 0.898 , as tested by SPSS 23.0 .

Subsequently, to assess the fitness of the model, confirmatory factor analysis (CFA) is conducted. Before CFA, the preliminary model fit indicators were: $\mathrm{CMIN} / \mathrm{DF}=4.186(\mathrm{P}=0.000), \mathrm{GFI}=0.763, \mathrm{NFI}=0.706, \mathrm{IFI}=0.759$, $\mathrm{CFI}=0.757$, and RMSEA $=0.106$ which they denoted that the indicators do not meet the thresholds of the goodness of model fit. After conducting the CFA, we extracted the factor loadings and then eliminated all factors loading below 0.5 , as shown in Table 3. While the results exposed a poor-fit model, we checked the covariance ratios between the observed variables, and we found that the new model fit indicators after CFA are CMIN/DF $=2.924(\mathrm{P}=0.000), \mathrm{GFI}=0.905, \mathrm{NFI}=0.903, \mathrm{IFI}=0.913, \mathrm{CFI}=0.912$, and $\mathrm{RMSEA}=0.069$ which affirm the overall model fit (Arasli et al., 2017).

Table 3. Summary of factor loading and composite reliability

\begin{tabular}{|c|c|c|}
\hline Construct / Items & $\begin{array}{l}\text { Factor } \\
\text { Loadings }\end{array}$ & $\begin{array}{l}\text { Composite } \\
\text { Reliability }\end{array}$ \\
\hline Traditional Marketing & & 0.864 \\
\hline $\begin{array}{l}\text { I am satisfied with the advertising campaigns of this airline on traditional media: such } \\
\text { as radio and television. }\end{array}$ & 0.82 & \\
\hline $\begin{array}{l}\text { The intensity and volume of the advertising campaigns of this airline using traditional } \\
\text { media such as radio and television have met my expectations. }\end{array}$ & 0.82 & \\
\hline $\begin{array}{l}\text { The campaigns of this airline on traditional media such as radio and television are } \\
\text { acceptable. }\end{array}$ & 0.82 & \\
\hline I feel motivated by this airline's traditional media advertisements. & 0.68 & \\
\hline Social Media Marketing & & 0.798 \\
\hline $\begin{array}{l}\text { I am satisfied with received information from other customers about this airline on } \\
\text { social media. }\end{array}$ & 0.68 & \\
\hline Information received from other customers on social media has met my expectations. & 0.77 & \\
\hline $\begin{array}{l}\text { Compared to other received information from other sources, the received information } \\
\text { on social media about this airline is acceptable. }\end{array}$ & 0.70 & \\
\hline I like, comment or share any of this airline's pictures or videos on social media. & - & \\
\hline I feel motivated by this airline's posts, videos, or images. & 0.74 & \\
\hline $\begin{array}{l}\text { I find this airline's page useful or informative with respect to keeping me up-to-date } \\
\text { about new offers. }\end{array}$ & 0.60 & \\
\hline $\begin{array}{l}\text { The airlines' posted information improves my awareness of buying options and } \\
\text { decisions. }\end{array}$ & 0.84 & \\
\hline $\begin{array}{l}\text { Reviews and comments of previous users on social media about this airline help me } \\
\text { take a better future decision. }\end{array}$ & - & \\
\hline Brand Trust & & 0.805 \\
\hline This airline is a professional airline company. & 0.64 & \\
\hline This airline always fulfills its commitments. & 0.77 & \\
\hline I trust the employees of this airline for service provision. & 0.59 & \\
\hline This airline tries to keep the information of their customers secure and anonymous. & 0.68 & \\
\hline $\begin{array}{l}\text { Others' opinions on social media do not change my preference or trust in this airline } \\
\text { company. }\end{array}$ & - & \\
\hline I feel that I can trust this airline company completely. & 0.62 & \\
\hline I prefer to fly with this airline even if they're not highly active or visible on social media. & 0.53 & \\
\hline Purchase Intention & & 0.818 \\
\hline I prefer to buy this airline's tickets more than any other available airlines. & 0.71 & \\
\hline I am willing to recommend others to buy from this airline. & 0.81 & \\
\hline I intend to fly again with this airline in the future. & 0.84 & \\
\hline I would strongly recommend this airline to everyone. & 0.78 & \\
\hline I would like to come back to this airline in the future. & 0.76 & \\
\hline $\begin{array}{l}\text { Negative reviews of other social media users about this airline company decrease } \\
\text { my purchase intentions. }\end{array}$ & - & \\
\hline
\end{tabular}

The construct validity examines the extent to which a scale truly measures a construct of interest, including convergent and discriminant validity (Peter, 1981). Almost all within-construct correlations were larger than correlations between construct items, implying convergent and discriminant validity.

\subsubsection{Convergent Validity}

Convergent validity refers to the degree to which two measures of constructs that theoretically should be related, are related (Anderson \& Gerbing, 1988). We examine convergent validity or the extent to which blocks of items 
converge in their representation of the theoretical construct. It requires each measurement item to correlate strongly with its related construct, and prior research suggests that the standardized loadings should equal at least 0.50 , and ideally 0.70 or higher. As we discussed, factor loadings below than $0 / 50$ are excluded and other loadings ranged from 0.53 to 0.84 in Table 3 , demonstrate satisfactory convergent validity, as factor loadings. The convergent validity test also needs the average variance extracted (AVE) indicator to meet the threshold of 0.5 (Hair et al., 2010). All items in our study achieved this threshold. Further, our model exposed that all composite reliability values that listed between 0.798 and 0.864 are greater than corresponding AVEs, and simultaneously satisfies $>.70$ which are shown in Table 4 (Bagozzi \& Yi, 1988).

\subsubsection{Discriminant Validity}

Discriminant validity is demonstrated by evidence that measures of constructs that theoretically should not be highly related to each other are, in fact, not found to be highly correlated to each other. The correlation of the latent variable scores with the measurement items needs to show an appropriate pattern of loadings, one in which the measurement items load highly on their theoretically assigned factor. Fornell \& Larcker (1981) suggested that the square root of AVE in each latent variable could be used to establish discriminant validity if this value is larger than other correlation values among the latent variables. Based on Table 4 the square roots of the AVE (on the diagonal) are greater than their corresponding inter-construct correlations values, in support of the discriminant validity of the measurement scales. Then, all maximum squared variances (MSV) and average squared variances (ASV) should respectively lower than their corresponding AVEs.

Table 4. Fornell-Larcker criteria analysis for checking discriminant validity

\begin{tabular}{c|cccccccc}
\hline & CR & AVE & MSV & ASV & BT & TM & SM & PI \\
\hline BT & 0.805 & 0.565 & 0.542 & 0.432 & 0.752 & & & \\
TM & 0.864 & 0.608 & 0.442 & 0.316 & 0.665 & 0.780 & & \\
SM & 0.798 & 0.528 & 0.412 & 0.295 & 0.559 & 0.642 & 0.727 & \\
PI & 0.818 & 0.585 & 0.542 & 0.265 & 0.736 & 0.304 & 0.401 & 0.765 \\
\hline
\end{tabular}

\section{EVALUATION OF FINDINGS}

As estimated, based on the final results shown in Table $5, \mathrm{H} 1$ indicated that traditional marketing activities would have a positive effect on customers' brand trust. The results were significant $(\beta=0.461 ; p=.005)$, and thus $\mathrm{H} 1$ is supported.

$\mathrm{H} 2$ proposed that social media marketing activities would have a positive effect on customers' brand trust. According to the related results $(\beta=0.759 ; p=.000)$ which is reported in Table 5 , the second hypothesis is also supported. The findings related to $\mathrm{H} 1$ and $\mathrm{H} 2$ confirm that social media marketing has a stronger effect on brand trust towards the airline company than traditional marketing.

H3 suggested that customers' brand trust has a positive effect on their purchase intentions towards the airline company. The given results $(\beta=0.832 ; p=0.000)$ supports H3. This finding simply explains that the customers' intention to buy a ticket from an airline, can be affected by the level of their trust in the brand.

Table 5. Hypotheses testing and coefficients

\begin{tabular}{|c|c|c|c|c|c|c|c|}
\hline Hypothesis & Independent Variable & Dependent Variable & $\beta$ & S.E & $\mathrm{t}$-value & $p$-value & $\begin{array}{c}\text { Supported/ } \\
\text { Not } \\
\text { Supported }\end{array}$ \\
\hline $\mathrm{H} 1$ & Traditional Marketing & Brand Trust & 0.461 & 0.079 & 2.567 & ** & Supported \\
\hline $\mathrm{H} 2$ & Social Media Marketing & Brand Trust & 0.759 & 0.090 & 6.784 & *** & Supported \\
\hline H3 & Brand Trust & Purchase Intention & 0.832 & 0.108 & 8.628 & *** & Supported \\
\hline
\end{tabular}

The findings imply that social media marketing employed by a company is imperative in influencing customers' trust in the brand. This result validates the declarations in the works of Moorman et al. (2002) and De Pelsmacker et al. (2002) which stated interactive media marketing has a positive influence on consumers' brand trust. Thus, airline companies should adopt strategies that increase travelers' level of satisfaction and reinforce their brand trust positively. The positive trust notions toward the airline company reflect consumers' beliefs that the examined airline company would honor its promises and commitments fulfilled and maintain its level of professionalism in rendering its services. So, with matching the offered services with the values of consumers, airline companies can stimulate customers to form positive attitudes and strong positive intentions towards flying again with the same airline company. This supports the study of Kim and Ko (2012) and Naylor et al. (2012). Given these results, airlines should ensure that their image and mission promised to customers via social media fall in with what customers believe a delightful flight experience is. This may be explained by 
stating that if travelers trust the tested airline company, they are more likely to repurchase its services, and vice-versa. Therefore, the airline companies can affect customers' trust and intentions to fly with them again. This result corroborates the studies of Everard and Galletta (2006), Ling et al. (2011), Aghekyan-Simonian et al. (2012), and Mansour et al. (2014).

As discussed, although there are positive significant effects of both types of marketing on customers' brand trust, social media marketing has a stronger impact, which in turn affects the customers' purchase intentions and decisions to repurchase the services are offered by the airline. The given results are visualized in Figure 2 as follows:

Figure 2. Estimated model

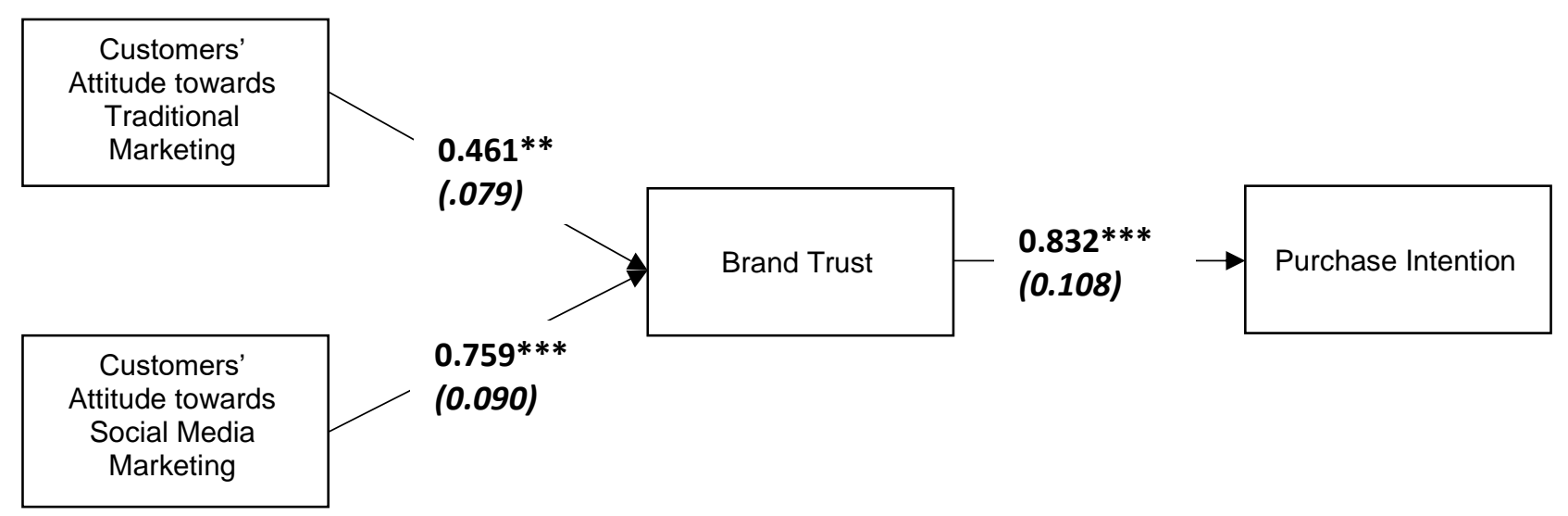

Note: ${ }^{* *} \mathrm{p}<0.05,{ }^{* * *} \mathrm{p}<0.01$. Unstandardized coefficients are used and standard errors are in parentheses.

Our findings suggest that it is beneficial to invest in social media advertising activities. The study reveals that campaigns, offers, information and follow-ups on social media are significant drivers of brand trust, followed by the concernment of the content and its popularity among clients' social networks. Another fundamental outcome of the study is that in contrast to what some people might think, traditional marketing still plays an essential role in affecting brand trust and purchase intentions of customers consequently.

\section{MANAGERIAL AND THEORETICAL IMPLICATIONS}

\subsection{Managerial Implications}

This research offers additional insight into explaining how traditional and social media marketing contributes to brand trust, then how brand trust plays a major role in defining the behavior of customers and enhancing their purchase intentions. It is suggested that Turkish airline companies should formulate online advertising strategies that create higher satisfaction and meet the expectations of consumers, thus achieving positive purchase intention attitudes from consumers. This infers that to increase sales via direct purchases from their ticket sales offices or online ticketing, airline companies should advertise more on social media about the different usage contexts and occasions. Nowadays, price saving can be a major driver for purchase intention. This means that a greater amount of money saved by consumers in obtaining the best offer for a given price with high perceived benefits, the more likely it will result in greater positive purchase intentions and a more positive attitude towards flying with the same company over and over again. However, just lowering the prices will not do the work itself. Companies should take advantage of using social media advertising and attract as many customers as possible.

Furthermore, the companies should not stop using traditional media as digital media is not embraced by every age group in society. As can be seen from the results, traditional media has a significant effect on brand trust.

Airlines should be aware of the importance of providing after-sales customer care via telephone to receive complaints, social media client communication channels such as Facebook, Instagram, and Twitter and the option of presenting boarding passes by SMS not only by paper. This illustrates the importance of diversifying the advertising plan of an airline company via traditional and social media to inform consumers about offers and promotions.

Airline companies could also add free customer care call centers, email and an active social media presence. Companies can provide incentives to their social media users to share and spread their presence, campaigns, ads, and content on social media among their networks, by offering discounts or a free ticket to a selected 
number of the page followers that would share their contents. Companies can also hire opinion leaders or celebrities in their target markets to advertise their campaigns, influence the public, and attract people to purchase their services.

Companies that intend to implement an effective social media advertising campaign should consider the benefits, values, and advantages they can offer to their clients and then explore the drivers of brand trust to their customers.

Lastly, the relevance of marketing content is an important factor affecting brand trust; therefore, companies should always pay attention to what their clients are expecting from their purchases. Airlines should also conduct individual research or observations to better understand their clients' needs and translate this knowledge into higher quality service and customer satisfaction, thus they can increase the level of their customers' brand trust and, positively affect their purchase intentions.

\subsection{Theoretical Implications}

From a theoretical point of view to the researchers' knowledge, the effect of social media and traditional marketing on brand trust have been measured simultaneously in the civil aviation field for the first time in the literature. By doing so, the differences between these two marketing methods have been defined and the chance of comparing the effects of the two different methods on brand trust formation has been created.

\section{LIMITATIONS AND FUTURE RESEARCH}

This work contained several limitations. First, the present study investigated only the effects of traditional and social media marketing on brand trust and purchase intention. Additional dimensions such as brand equity, brand loyalty, and brand commitment could be added to the study to validate the effectiveness of employing cross-media advertising plans as a tool to impact customers' purchase intention. Furthermore, it would be helpful to enlarge the sample examined to include a larger, more generalizable sample.

Brand trust and purchase intention are also heavily affected by the way, in which a company presents itself on social media and the level of interactivity and quick response rate to its followers' posts. Therefore, to enhance the understanding of the best effective social media marketing activities for airlines, future studies may include a greater number of airline companies and study the way they represent themselves on social media and focus on the effects of these specific behaviors, such as interactivity.

\section{DECLARATION OF CONFLICTING INTERESTS}

We would like to confirm that there is no known conflict of interest associated with this publication and there has been no financial support for this work that could have influenced its outcomes.

\section{REFERENCES}

Abzari, M., Ghassemi, R. A., \& Vosta, L. N. (2014). Analysing the Effect of Social Media on Brand Attitude and Purchase Intention: The Case of Iran Khodro Company. Procedia-Social and Behavioral Sciences, 143, 822-826. http://dx.doi.org/10.1016/j.sbspro.2014.07.483

Aghaei, I., \& Sokhanvar, A. (2019). Factors influencing SME owners' continuance intention in Bangladesh: a logistic regression model. Eurasian Business Review, 1-25.

Aghekyan-Simonian, M., Forsythe, S., Kwon, W. S., \& Chattaraman, V. (2012). The role of product brand image and online store image on perceived risks and online purchase intentions for apparel. Journal of Retailing and Consumer Services, 19(3), 325-331. http://dx.doi.org/10.1016/j.jretconser.2012.03.006

Ajzen, I. (1991). The theory of planned behavior. Organizational Behavior and Human Decision Processes, 50(2), $179-211$.

Aksoy, C., \& Dursun, Ö. O. (2018). A General Overview of the Development of the Civil Aviation Sector in Turkey. Electronic Journal of Social Sciences, 17 (67), 1060-1076.

Aksoy, S., Atilgan, E., \& Akinci, S. (2003). Airline services marketing by domestic and foreign firms: differences from the customers' viewpoint. Journal of Air Transport Management, 9(6), 343-351.http://dx.doi.org/10.1016/S09696997(03)00034-6

Anderson, J. C., \& Gerbing, D. W. (1988). Structural equation modelling in practice: A review and recommended two-step approach. Psychological bulletin, 103(3), 411.

Arasli, H., Bahman Teimouri, R., Kiliç, H., \& Aghaei, I. (2017). Effects of service orientation on job embeddedness in hotel industry. The Service Industries Journal, 37(9-10), 607-627.

Atalik, O., \& Arslan, M. (2009). Wisdom of domestic customers: An empirical analysis of the Turkish Private Airline Sector. International Journal of Business and Management, 4(7), 61.http://dx.doi.org/10.5539/ijbm.v4n7p61 
Barnes, N. G., Lescault, A. M., \& Wright, S. (2013). Fortune 500 are bullish on social media: Big companies get excited about Google+, Instagram, Foursquare and Pinterest. University of Massachusetts Dartmouth Centre for Marketing Research.

Bagozzi, R. P., \& Yi, Y. (1988). On the evaluation of structural equation models. Journal of the academy of marketing science, 16(1), 74-94.

Berthon, P. R., Pitt, L. F., Plangger, K., \& Shapiro, D. (2012). Marketing meets Web 2.0, social media, and creative consumers: Implications for international marketing strategy. Business Horizons, 55(3), 261271.http://dx.doi.org/10.1016/j.bushor.2012.01.007

Beukeboom, C. J., Kerkhof, P., \& de Vries, M. (2015). Does a virtual like cause actual liking? How following a brand's Facebook updates enhances brand evaluations and purchase intention? Journal of Interactive Marketing, 32, 26-36. http://dx.doi.org/10.1016/j.intmar.2015.09.003

Chaudhuri, A. \& Holbrook, M. B. (2001). The chain of effects from brand trust and brand affect to brand performance: The role of brand loyalty. Journal of Marketing, 65(2), 81-93.http://dx.doi.org/10.1509/jmkg.65.2.81.18255

Constantinides, E. (2006). The marketing mix revisited: towards the 21st century marketing. Journal of Marketing Management, 22(3-4), 407-438. http://dx.doi.org/10.1362/026725706776861190

De Pelsmacker, P., Geuens, M., \& Anckaert, P. (2002). Media context and advertising effectiveness: The role of context appreciation and context/ad similarity. Journal of Advertising, 31(2), 4961.http://dx.doi.org/10.1080/00913367.2002.10673666

Dehghani, M. \& Tumer, M. (2015). A research on effectiveness of Facebook advertising on enhancing purchase intention of consumers. Computers in Human Behavior, 49, 597-600.http://dx.doi.org/10.1016/j.chb.2015.03.051

Dijkmans, C., Kerkhof, P., \& Beukeboom, C. J. (2015). A stage to engage: Social media use and corporate reputation. Tourism Management, 47, 58-67. http://dx.doi.org/10.1016/j.tourman.2014.09.005

Doney, P. M. \& Cannon, J. P. (1997). An examination of the nature of trust in buyer-seller relationships. The Journal of Marketing, 35-51. http://dx.doi.org/10.2307/1251829

Drury, G. (2008). Opinion piece: Social media: Should marketers engage and how can it be done effectively? Journal of Direct, Data and Digital Marketing Practice, 9(3), 274-277.

Erdoğmuş, İ. E. \& Cicek, M. (2012). The impact of social media marketing on brand loyalty. Procedia-Social and Behavioral Sciences, 58, 1353-1360.

Espejel, J., Fandos, C., \& Flavian, C. (2008). Consumer satisfaction: A key factor of consumer loyalty and buying intention of a PDO food product. British Food Journal, 110(9), 865-881.http://dx.doi.org/10.1108/00070700810900585

Everard, A. \& Galletta, D. F. (2006). How presentation flaws affect perceived site quality, trust, and intention to purchase from an online store. Journal of Management Information Systems, 22(3), 56-95.http://dx.doi.org/10.2753/MIS07421222220303

Fornell, C., \& Larcker, D. F. (1981). Structural equation models with unobservable variables and measurement error: Algebra and statistics. Journal of marketing research, 382-388. http://dx.doi.org/10.2307/3150980

Gamboa, A. M., \& Gonçalves, H. M. (2014). Customer loyalty through social networks: Lessons from Zara on Facebook. Business Horizons, 57(6), 709-717.

Grewal, D., Monroe, K. B., \& Krishnan, R. (1998). The effects of price-comparison advertising on buyers' perceptions of acquisition value, transaction value, and behavioral intentions. The Journal of Marketing, 46-59.

Guennemann, F. \& Cho, Y. C. (2014). The effectiveness of product placement by media types: Impact of image and intention to purchase. Journal of Service Science (JSS), 7(1), 29-42.http://dx.doi.org/10.19030/jss.v7i1.8911

Ha, H. Y. \& Perks, H. (2005). Effects of consumer perceptions of brand experience on the web: Brand familiarity, satisfaction and brand trust. Journal of Consumer Behavior, 4(6), 438-452. http://dx.doi.org/10.1002/cb.29

Hair, J. F. (2010). Multivariate data analysis. Pearson Prentice Hall.

Hill, R. P. \& Moran, N. (2011). Social marketing meets interactive media: Lessons for the advertising community. International Journal of Advertising, 30(5), 815-838. http://dx.doi.org/10.2501/IJA-30-5-815-838

Hoy, M. G. \& Milne, G. (2010). Gender differences in privacy-related measures for young adult Facebook users. Journal of Interactive Advertising, 10(2), 28-45. http://dx.doi.org/10.1080/15252019.2010.10722168

Hsu, M. H., Chang, C. M., \& Chuang, L. W. (2015). Understanding the determinants of online repeat purchase intention and moderating role of habit: The case of online group-buying in Taiwan. International Journal of Information Management, 35(1), 45-56.

Hsu, Y. L. (2012). Facebook as international eMarketing strategy of Taiwan hotels. International Journal of Hospitality Management, 31(3), 972-980. http://dx.doi.org/10.1016/j.jhm.2011.11.005

lbáñez, V. A., Hartmann, P., \& Calvo, P. Z. (2006). Antecedents of customer loyalty in residential energy markets: Service quality, satisfaction, trust and switching costs. The Service Industries Journal, 26(6), 633-650.

Kang, J., Tang, L., \& Fiore, A. M. (2014). Enhancing consumer-brand relationships on restaurant Facebook fan pages: Maximizing consumer benefits and increasing active participation. International Journal of Hospitality Management, 
$36,145-155$.

Kim, A. J. \& Ko, E. (2012). Do social media marketing activities enhance customer equity? An empirical study of luxury fashion brand. Journal of Business Research, 65(10), 1480-1486.http://dx.doi.org/10.1016/j.jbusres.2011.10.014

Lavinsky, D. (2013). Forbes Welcome. Forbes.com. Retrieved: 17 October 2015 from: http://www.forbes.com

Lin, L. Y., \& Lu, C. Y. (2010). The influence of corporate image, relationship marketing, and trust on purchase intention: the moderating effects of word-of-mouth. Tourism review, 65(3), 16-34.

Ling, K. C., bin Daud, D., Piew, T. H., Keoy, K. H., \& Hassan, P. (2011). Perceived risk, perceived technology, online trust for the online purchase intention in Malaysia. International Journal of Business and Management, 6(6), 167.

Mansour, K. B., Kooli, K., \& Utama, R. (2014). Online trust antecedents and their consequences on purchase intention: An integrative approach. Journal of Customer Behavior, 42.http://dx.doi.org/10.1362/147539214X14024779343677

Matzler, K., Bidmon, S., \& Grabner-Kräuter, S. (2006). Individual determinants of brand affect: The role of the personality traits of extraversion and openness to experience. Journal of Product \& Brand Management, 15(7), 427-434. http://dx.doi.org/10.1108/10610420610712801

Matzler, K., Grabner-Kräuter, S., \& Bidmon, S. (2006). The value-brand trust-brand loyalty chain: An analysis of some moderating variables. Innovative Marketing, 2(2), 76-88.

McKnight, D. H., Choudhury, V., \& Kacmar, C. (2002). Developing and validating trust measures for e-commerce: An integrative typology. Information Systems Research, 13(3), 334-359.http://dx.doi.org/10.1287/isre.13.3.334.81

Mohamed, N., Hussein, R., Hidayah Ahmad Zamzuri, N., \& Haghshenas, H. (2014). Insights into individual's online shopping continuance intention. Industrial Management \& Data Systems, 114(9), 1453-1476.

Mohammad, A. A. S. (2012). The effect of brand trust and perceived value in building brand loyalty. International Research Journal of Finance and Economics, 85, 111-126.

Moorman, M., Neijens, P. C., \& Smit, E. G. (2002). The effects of magazine-induced psychological responses and thematic congruence on memory and attitude toward the ad in a real-life setting. Journal of Advertising, 31(4), 27-40. http://dx.doi.org/10.1080/00913367.2002.10673683

Naylor, R. W., Lamberton, C. P., \& West, P. M. (2012). Beyond the "like" button: the impact of mere virtual presence on brand evaluations and purchase intentions in social media settings. Journal of Marketing, 76(6), 105-120.

Orhan, G., \& Gerede, E. (2013). A study of the strategic responses of Turkish airline companies to the deregulation in Turkey. Journal of Management Research, 5(4), 34. http://dx.doi.org/10.5296/jmr.v5i4.4201

Preece, J., Nonnecke, B., \& Andrews, D. (2004). The top five reasons for lurking: improving community experiences for everyone. Computers in human behavior, 20(2), 201-223.http://dx.doi.org/10.1016/j.chb.2003.10.015

Rodgers, R. F., Melioli, T., Laconi, S., Bui, E., \& Chabrol, H. (2013). Internet addiction symptoms, disordered eating, and body image avoidance. Cyberpsychology, Behavior, and Social Networking, 16(1), 5660.http://dx.doi.org/10.1089/cyber.2012.1570

Safko, L., \& Brake, D. K. (2009). The Social Media Bible: Tactics. Tools \& for Business Success, Hoboken, New Jersey.

Saleem, M. A., Zahra, S., \& Yaseen, A. (2017). Impact of service quality and trust on repurchase intentions-the case of Pakistan airline industry. Asia Pacific Journal of Marketing and Logistics, 29(5), 1136-1159.

Schivinski, B., \& Dąbrowski, D. (2013). The impact of brand communication on brand equity dimensions and brand purchase intention through facebook. GUT FME Working Paper Series A. Gdansk (Poland): Gdansk University of Technology, Faculty of Management and Economics, 4(4), 1-24.

Sevkli, M., Oztekin, A., Uysal, O., Torlak, G., Turkyilmaz, A., \& Delen, D. (2012). Development of a fuzzy ANP based SWOT analysis for the airline industry in Turkey. Expert systems with Applications, 39(1), 1424.http://dx.doi.org/10.1016/j.eswa.2011.06.047

SGHM, (2018). 2018 annual report. Retrieved on 19 December 2019 from:http://web.shgm.gov.tr/documents/sivilhavacilik/files/pdf/kurumsal/faaliyet/2018.pdf

Sheth, J. N. \& Parvatlyar, A. (1995). Relationship marketing in consumer markets: Antecedents and consequences. Journal of the Academy of Marketing Science, 23(4), 255-271.http://dx.doi.org/10.4135/9781452231310.n7

Statcounter (2011). Top 7 Social Media Sites in Turkey. Retrieved on 17 November 2015 from Statcounter:http://gs.statcounter.com

Sung, Y. \& Kim, J. (2010). Effects of brand personality on brand trust and brand affect. Psychology \& Marketing, 27(7), 639661. http://dx.doi.org/10.1002/mar.20349

Tariq, M. I., Nawaz, M. R., Nawaz, M. M., \& Butt, H. A. (2013). Customer perceptions about branding and purchase intention: A study of FMCG in an emerging market. Journal of Basic and Applied Scientific Research, 3(2), 340-347.

Teimouri, R. B., Arasli, H., Kiliç, H., \& Aghaei, I. (2018). Service, politics, and engagement: A multi-level analysis. Tourism management perspectives, 28, 10-19.

The Economist. (2015). Domestic Bliss. Retrieved on 17 September 2015, from Economist:_http://www.economist.com 
Todor, R. D. (2016). Blending traditional and digital marketing. Bulletin of the Transilvania University of Brasov. Economic Sciences. Series $V, 9(1), 51$.

Torlak, G., Sevkli, M., Sanal, M., \& Zaim, S. (2011). Analyzing business competition by using fuzzy TOPSIS method: An example of Turkish domestic airline industry. Expert Systems with Applications, 38(4), 3396-3406. http://dx.doi.org/10.1016/j.eswa.2010.08.125

Tsai, H. T., Huang, L., \& Lin, C. G. (2005). Emerging e-commerce development model for Taiwanese travel agencies. Tourism Management, 26(5), 787-796. http://dx.doi.org/10.1016/j.tourman.2004.04.009

Ülkü, T. (2015). A comparative efficiency analysis of Spanish and Turkish airports. Journal of Air Transport Management, 46, 56-68.

Vitolins, M. Z., Rand, C. S., Rapp, S. R., Ribisl, P. M., \& Sevick, M. A. (2000). Measuring adherence to behavioral and medical interventions. Controlled clinical trials, 21(5), S188-S194.

Waters, R. D., Canfield, R. R., Foster, J. M., \& Hardy, E. E. (2011). Applying the dialogic theory to social networking sites: Examining how university health centers convey health messages on Facebook. Journal of Social Marketing, 1(3), 211-227. http://dx.doi.org/10.1108/20426761111170713

Weinberg, B. D., \& Pehlivan, E. (2011). Social spending: Managing the social media mix. Business Horizons, 54(3), 275282. http://dx.doi.org/10.1016/j.bushor.2011.01.008

Weinberg, T. (2009). The new community rules: Marketing on the social web. "O'Reilly Media, Inc.", Jul 8.

Wongleedee, K. (2015). Marketing mix and purchasing behavior for community products at traditional markets. ProcediaSocial and Behavioral Sciences, 197, 2080-2085.

Worldbank (2016). Internet users (per 100 people). Retrieved on 7 December 2019 from Worldbank:https://datacatalog.worldbank.org/internet-users-100-people-2

Wsi, (2013). Digital Minds: 12 Things Every Business Needs to Know about Digital Marketing. Victoria: Friesen Press, 7.

Zarrella, D. \& Zarrella, A. (2010). The Facebook Marketing Book. "O’Reilly Media, Inc.", Dec 21.

Zeithaml, V. A. (1988). Consumer perceptions of price, quality, and value: a means-end model and synthesis of evidence. The Journal of Marketing, 2-22. http://dx.doi.org/10.2307/1251446

Zhao, S., Grasmuck, S., \& Martin, J. (2008). Identity construction on Facebook: Digital empowerment in anchored relationships. Computers in Human Behavior, 24(5), 1816-1836.http://dx.doi.org/10.1016/j.chb.2008.02.012

Zheng, X., Lee, M., \& Cheung, C. M. (2017). Examining e-loyalty towards online shopping platforms: The role of coupon proneness and value consciousness. Internet Research, 27(3), 709-726. 